Rosen, Ilana. "Friedmann, Robbie. 2014. 28 Letters - the Short Life of Renée (Baba) Friedmann on Not So Calm Waters. San Francisco, London: Blurb.com. An English, Hungarian and Hebrew Edition. 440 pp." Hungarian Cultural Studies. e-Journal of the American Hungarian Educators Association, Volume 9 (2016): http://ahea.pitt.edu DOI: 10.5195/ahea.2016.239

\title{
Friedmann, Robbie. 2014. 28 Letters - the Short Life of Renée (Baba) Friedmann on Not So Calm Waters. San Francisco, London: Blurb.com. An English, Hungarian and Hebrew Edition. 440 pp.
}

\author{
Reviewed by Ilana Rosen, Ben Gurion University of the Negev
}

At the 2015 AHEA Conference held at Babeş-Bolyai University in Cluj-Napoca, Romania, Robert R. Friedmann (b. 1947), an American-Israeli Professor Emeritus of Criminal Justice at Georgia State University, presented his own family history through some twenty letters that his late mother Renée (Baba) Friedmann (1911-1947) of Kolozsvár-Cluj had written to her younger sister Edith-Dita (1921-1999) of Palestine-EY ("Eretz Yisrael," Heb. 'Land of Israel') and a few Red Cross queries sent mostly in Edith-Dita's name and more rarely in Renée's. This correspondence (whose missing counterpart, of the letters written by Edith-Dita to Renée, is echoed throughout Renée's letters and thus enables us readers to get an idea of what and how Edith-Dita wrote) lasted from 1941, when Edith-Dita emigrated to EY, until October 1947, three weeks before Renée died of postnatal complications six days after giving birth to Robert-RobbieVictor-Rechavia.

Up until the closing sentences of his oral presentation Friedmann, somewhat enigmatically, referred to his mother by her maiden family-name Goldman (although she was married to his father Richard-Rudolph-Rezsö Friedmann since 1938), thus postponing the audience's realization of the real ties between the speaker and his subject. This way he was also leading us in his footsteps as he found out first, only at age thirty-one, that Irén Gerö Friedmann, his father's second wife whom he had always known as his mother, was not his biological mother, and some twenty years later, following Edith-Dita's death, that Renée Goldman Friedmann was his "real" mother. In 28 Letters Friedmann explains that Irén, who had lost her first husband in the Holocaust, became his nanny or surrogate mother since his early infancy until he was three, with only her mother to help her, as Robbie's father Rezső had left illegally to EY soon after Renée's death. In 1950, once Irén and Robbie (and Irén's mother) were allowed to leave Romania for Israel, Irén married Rezső, and Robbie remained their only child. To Rezső's strict request, for decades no one of their relatives, including Edith-Dita's family whom the Friedmanns referred to as family friends of the same town, ever told Robbie of Renée; but when Robbie got married Irén disclosed to his wife that she was not his biological mother. Eventually it was Teddy Lowenkopf, Edith-Dita's widower, who in 1999 gave Robbie the letters revealing all these complexities.

$(\mathrm{cc}) \mathrm{BY}$

ULIS D-Serle
New articles in this journal are licensed under a Creative Commons Attribution 4.0 International License.

This journal is published by the University Library System of the University of Pittsburgh as part of its D-Scribe Digital Publishing Program and is cosponsored by the University of Pittsburgh Press 
Rosen, Ilana. "Friedmann, Robbie. 2014. 28 Letters - the Short Life of Renée (Baba) Friedmann on Not So Calm Waters. San Francisco, London: Blurb.com. An English, Hungarian and Hebrew Edition. 440 pp." Hungarian Cultural Studies. e-Journal of the American Hungarian Educators Association, Volume 9 (2016): http://ahea.pitt.edu DOI: 10.5195/ahea.2016.239

Friedmann's family epistolary-memoir includes, in addition to the twenty-eight letters and queries, a general-historical Prologue and a personal-familial Epilogue in which the author-editor first introduces and later annotates the letter succession, at times explicating its parts, like the "nyugodt meder" or "calm waters" idiom (referring to Psalms 23, 2) that Renée uses in her letters. Because of the fragmentary and elliptical nature of this and possibly any partial correspondence, the two closure parts of prologue and epilogue are much needed for the understanding of the events and people around whom the correspondence revolves, even though these two parts necessarily also lock up the "narrative" of the correspondence within the outlook of the author-editor, including his learned social-studies insights; whereas in real time and for the acting figures, there could have been other ways of looking at the flow of their lives. For example, in her letters Renée seems to have been rather preoccupied with body, food and clothing issues, but these issues hardly captures the attention of the male author-editor, her son, who is more fascinated by the life and soul of his newly-discovered biological mother, her thoughts, views, emotions and the imprints of the Holocaust she lived through but hardly wrote about in her letters to her sister.

Indeed, in her letters Renée refers explicitly to the Holocaust only once (in a letter written on Nov. 6, 1945), saying that this experience was far from an "érdekes epizoda" or "interesting episode," as Edith-Dita must have called it in a previous letter, and explaining that she (Renée) does not want to sadden her sister and therefore can only describe what she went through in general terms. She then adds that immediately upon their arrival to Auschwitz she was separated from their father and that was the last time she saw or heard of him (not a word is written in this entire book about the family's mother, but Friedmann later learned from his newly-discovered relatives that this grandmother of his died around 1931 and also that after Renée and before Edith-Dita she had a son, who died at the age of seven).

Yet, a careful reading of Renée's letters shows that despite its overt absence, the Holocaust experience is heavily burdening Renée's short-lived post-Holocaust life. To start with, just as she worries about the whereabouts of her father she also cares and writes about other relatives, as well as about friends and acquaintances, at times almost making her letters seem like a virtual Search Bureau of Missing Relatives (which was at that time an actual section of the Jewish Agency or Sochnut). In addition, even though she writes minimally about the camps she does enlarge about her post-Holocaust life, which started at a convalescence center at Stockholm, Sweden, where she stayed for nine months after liberation from the camps; from Stockholm she writes in detail about going to opera, ballet, movies and museums as well as about receiving a large piece of cloth for sewing a new suit. Clothes, in turn, make Renée aware of her body and -as with many survivors who have shortly beforehand suffered famine -- of her rapid weight gain and, by extension, of her new body and self image. (For a survivor couple's correspondence turned into a novel by the couple's son and depicting similar experiences to those of Renée Friedmann see: Péter Gárdos, Hajnali láz. Budapest: Libri, 2015; for this novel's revised English 
Rosen, Ilana. "Friedmann, Robbie. 2014. 28 Letters - the Short Life of Renée (Baba) Friedmann on Not So Calm Waters. San Francisco, London: Blurb.com. An English, Hungarian and Hebrew Edition. 440 pp." Hungarian Cultural Studies. e-Journal of the American Hungarian Educators Association, Volume 9 (2016): http://ahea.pitt.edu DOI: 10.5195/ahea.2016.239

edition see: idem., Fever at Dawn. Trans. Elizabeth Szász. Boston: Houghton Mifflin Harcourt, 2016; as well as the film by the same title directed by Péter Gárdos, 2015.) Moreover, ever since she returns to Kolozsvár and reunites with her husband after more than three years of separation, all she cares about is leaving for EY, joining her sister and thus rehabilitating her shattered life. Life "on not so calm waters," as the book's sub-title has it, now gives Renée the gift of a first pregnancy at the age of thirty-six, which makes her postpone the emigration dream until sometime after the expected delivery. Finally, Renée writes not only about her personal, family and social life but also about the newly rehabilitated Jewish community of Kolozsvár. For example, she notices that this survivor community now cares more about Jewish holidays and about its own Jewish identity; this realization cannot but remind her of their -- including her personal -- suffering just a few years back and further strengthens her wish to break away from these tormenting memories.

Notwithstanding all that Renée herself must have gone through, as expected from a bunch of letters addressed to the addressor's faraway and much-younger sister, the drama of Renée's letters is all about Edith-Dita's giving up a life of relative comfort in a Central-European Jewish family of shopkeepers (the family leather-products store is mentioned several times in the correspondence) for the sake of becoming a pioneer (Heb. halutzah, a life course resembling that of the well known Hannah Senesh or Anikó Szenes of Budapest, 1921-1944, who left for EY in 1939, two years before Edith-Dita) and the hardships following such a move for both the young pioneer and her family. Indeed, Renée's first few letters, of 1941-1943, reflect her worrying about Edith-Dita including offering to send her whatever she needs in her new, frugal life. Surprisingly, in 1945-1947, too, it is still Renée who is invariably on the giving side while EdithDita always remains on the receiving side, with this give-and-take relationship including both clothes or other useful items and emotional support. Apparently, the ten-year age-difference between the two sisters and their bonding in the face of the tragedies that befell their kernel family, are stronger than shoah history and psychology.

As for the author and editor of this moving epistolary memoir, by going through this reconnaissance process and publishing his decades-old newly-discovered family correspondence that is highlighted by the secret he revealed among its pages, Robbie Friedmann treads a path that is on the one hand much trodden nowadays by many second-generation persons in the contexts of World War II and immigration, be they researchers, writers, journalists, filmmakers or so-called ordinary people; on the other hand, each such manuscript or even just a heap of documents has its unique story/ies, atmosphere and later implications for the relatives of the documents' main protagonist, as well as for much wider readership circles. In the case of the volume at hand what comes through so powerfully apart from its main revelation is the many desertions and losses suffered by so many of its protagonists starting from the early deaths of the Goldman brother and mother, going through the great losses in the Holocaust of the Goldman, Friedmann and Gerö families, through Rezső's leaving behind his orphaned infant son and 
Rosen, Ilana. "Friedmann, Robbie. 2014. 28 Letters - the Short Life of Renée (Baba) Friedmann on Not So Calm Waters. San Francisco, London: Blurb.com. An English, Hungarian and Hebrew Edition. 440 pp." Hungarian Cultural Studies. e-Journal of the American Hungarian Educators Association, Volume 9 (2016): http://ahea.pitt.edu DOI: 10.5195/ahea.2016.239

heading for EY (vaguely hoping to marry Edith-Dita, as Robbie Friedmann discloses in his book, a hope that turned out as vain), through Irén's uncertainty about her future while looking after Rezsö's son, through the distance forced on Edith-Dita, her husband Teddy and their three daughters vis-à-vis their nephew and cousin Robbie, and ending with Robbie's inconsolable agony of "too late."

In the face of such losses and voids, these humble, unassuming family writings may be -or might retrospectively be interpreted as -- the protagonists' reaching out to their closest relatives and most meaningful readers and wishing to pass them legacies that in real time neither of the two sides could have even conceived of. In the case of 28 Letters, judging by the tone of the parts written by Robbie Friedmann himself, one can say that he seems or "reads as" very much resigned to, albeit also moved by, the revelation of his "real" mother. Quite similarly, Renée (Baba) Friedmann, whom Robbie has known and will forever know only through her 1940s letters to her sister, likewise emerges from her letters as a person with great capacities for composure, compassion, acceptance and hopefulness despite all her life's disasters. Thus she, too, comes through, or "reads" just like her son, whom she has never seen. 